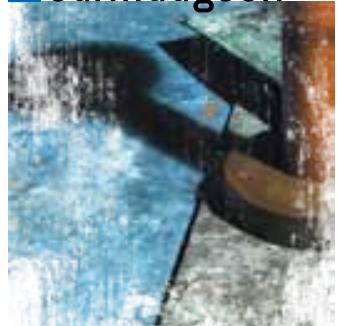

\title{
One Peut-Être, Two Peut-Être, Three Peut-Être, More
}

Stan Kelly-Bootle, Author

Puns and allusions

0 ne is always loath to explain a joke. In face-to-face badinage, the joker can judge the comprehension of the jokees from their immediate reactions. Failing to win the approving smiles, chuckles, or belly laughs, the raconteur has a choice of remedies including the Quick Exit Strategy ("What a dumb crowd. I'm out of here!"). The modest teller will accept the blame ("Oh, I forgot to mention that the mother-in-law was a blond Republican Fortran programmer!") and order drinks all around. It's the bore unwilling to accept defeat who embarks on a detailed analysis heralded by an aggressive, "You don't get it, do you?"

This rhetorical affront, one that has wormed its annoying way into many areas of contemporary polemic, is the ultimate deterrent to goodwill and reasonable discourse. If you don't "get" something, as opposed to merely not understanding all its finer ramifications, the feeling is conveyed that you are forever outside humanity's caring fold. Pascal lovers don't "get" C, and deep C fishers don't "get" C++. And, naturally, vice-versa, across a chasm of misunderstanding. Moreover, they are clearly never going to "get it," so brand the mark of the beast on their foreheads as they slink back to their obscure North Country polytechnics. ${ }^{1}$

When trying to raise a laugh with my writing, as with, say, this month's title, I lack the stand-up comic's instant feedback, forcing me to imagine, from previous reader encounters, what proportion of giggles, groans, and indifferent silences might ensue. Even when writing "straight" TechTalk, the author and publisher face the ancient "target audience" problem. Honest publicity for the Intermediate Guide to the Pluperfect Subjunctive in Early-Modern Hittite will tell you up-front: "This book is aimed at all intermediate students of early-modern Hittite grammar, especially those with an interest in the pluperfect-subjunctive verb conjugations and disposable cash to the tune of \$79.99."
Sneaky publishers might chance the additional, generalizing bait: "Beginners and advanced students, even Ph.D.s and professors, interested in other verb tenses of proto- and late-Hittite will surely find this treatment equally useful." Amazon will provide the enticing information that "those who bought the Intermediate Guide to the Pluperfect Subjunctive in Early-Modern Hittite also bought Cripple Clarence Lofton: Boogie Woogie Pioneer and Algol-68 on Ten Dollars a Day." In the competitive IT Conference Caravanserai, we find the most blatant enumerations under the banner, "Who Should Attend?" When you take the set-union of the welcomed invitee classes, it amounts to "any member of Homo sapiens (or related primate species) anxious to enjoy a week's company-paid vacation in warmer climes with free plastic carrier bags and discreet adult diversions."

Over the years, I've tried to adjust my style and content (and I hate to confess, my professed opinions) to suit what I could glean of the target reader's expertise and gullibility. What am I saying? A slip of a tongue, a fleeting lapis lazuli. My readers are never provably gullible. Skeptical of my truths, perhaps, yet I've never once tested them with intentional lies (with the possible exception of the previous statement). There's this vital, oft-neglected distinction between ignorance and dumbth. ${ }^{2}$ Clearly, authors can only guess at their readers' lexical awareness (the old educational lottery?) and powers of deduction and imagination (the old genetic lottery?).

Here we have a case in point. Meeting dumbth, some readers will write to say I've used a word that does not exist. One valid linguistic answer (at least in many descriptive, open-minded schools) is, "Well, it does now." Sometimes when the complainer says, "That word is not in my dictionary," I can rightly respond, "Buy a bigger dictionary." Nowadays, I tend to suggest an online search since printed dictionaries can't keep pace with our neologistic excesses. (I'm proud to mention that my children, to honor (or mock?) my famed omniscience, bought me a T-shirt reading, " $\mathrm{F}^{* * \star}$ Google, Ask Me!") 


\section{curmudgeon}

One reader whinged that I was always using words he or she did not know (gender is not always clear from a signature, as many a Sam and Gene can attest). I replied sympathetically, asking for a full list of their unknown words so I could avoid using them.

Returning to my title, I'm forced to admit that beyond what might seem to be an obvious pun, requiring a little French (peut-être means "perhaps, maybe") and knowledge of the children's game of counting potatoes, at which point the title at least sounds funny-there, I've already broken my rule against over-explicating a joke-you may still not grasp the full import of my waspish wit and unbounded, but lightly worn, erudition. Reluctantly, and risking your jealous scorn, I first remind you of Rabelais' lament, "Je m'en vais chercher le grand peut-être" ("I'll be looking out for the big maybe"). Nothing to laugh at yet, considering that the poet is speaking of death, the big unknown, the big perhaps. Move on to Vladimir Nabokov (1899-1977) and his baffling masterpiece Pale Fire (a quote from Shakespeare indicating the moon's poor reflection of the sun), where we find the poet John Shade also pondering his mortality, but fighting back with dark humor:

\section{L'if, lifeless tree! You great Maybe, Rabelais \\ The grand potato \\ I.P.H, a lay \\ Institute (I) of Preparation (P) \\ for the Hereafter $(\mathrm{H})$ or If, as we \\ Called it-a big if-engaged for one term \\ To speak on death...}

There's no end of chuckles for the word-sleuths here, and Nabokovians come to blows chasing their allusions. Amusingly, Nabokov himself was fond of rejecting many of the scholars' claimed solutions, saying that so-andso was a brilliant interpretation, and he wished he had thought of it at the time of writing.

To quickly note the puns and allusions: l'if is French for the yew tree, of ancient Celtic significance for both death and long life (which just shows how usefully flexible mythology can be); l'if can also be read as "the IF," well known to programmers who need to branch (trees again) conditionally to remote parts of the coding forest. To play the allusion game you must be bold enough to spot that we have been "learning tree languages from positive examples and membership queries." This also happens to be the title of a famous paper on algorithmic learning theory by Jérôme Besombesa and Jean-Yves Marion, in Theoretical Computer Science (Vol. 382, Issue 3), published the very week I moved back to England from the United States. Spooky beyond mere coincidence.

Nabokovians are obsessed by, and have a rare pet name for, spooky dates: fatidic. Look it up before complaining. Rabelais we've already met with his big peutétre/potato, perhaps the biggest "maybe" we mortals face. Nabokov loved, analyzed, and lectured on James Joyce's Ulysses but couldn't stand Finnegans Wake (far too cryptic). Perhaps there's a clue here, an echo of the Big Potato Famine that devastated Ireland in the 1840s. There they sang, "Oh the praties they are small and we dig them in the fall, and we eat them roots and all, over here." We now have three Frenchmen: the authors Jérôme and JeanYves plus Rabelais; why not a fourth, Pascal, whose Wager tests our deathbed faith in salvation?

We then transliterate IF to the Greek IPH, giving us the Institute of Preparation for the Hereafter. We can pause briefly to recall that IPHigenia, daughter of Agamemnon, had a close dice with death until saved by the virgin goddess ARTemis. The theme of art bestowing a form of immortality via the survival of your artistic corpus runs through the work of Russian poets such as Derzhavin and Nabokov. That noble image is abruptly (deliberately?) tarnished by the close positioning of the word preparation and the letter $H$. Yet the sequence IF, maybe, suppose, suppository confirms our linkages.

Undismayed by Nabokov's teasing denials of the wilder conjectures, dozens of Pale Fire exegetes have published conflicting readings (Google Pale Fire and try the fine Wiki main article for starters). It's something of a literary FLT (Fermat's Last Theorem or Mrs. Fermat's divine lettuce and tomato sandwich) with some significant differences. First, it's not quite clear what the puzzle is and whether a unique solution, if such there be, would stand out as unique. Next, the setter and adjudicator-nastily known as Vlad the Impaler by the many butterflies he pinned down (spreading, I think, is the in-name) as a leading lepidopterist-is no longer with us to vet (and denounce) solutions.

It was certainly sound book-commerce to keep the puzzle open as long as possible. I know of only two positive, off-the-cuff, extra-textual hints made by Nabokov during his lifetime: he confirmed that Botkin (a near-Russian-anagram for "nobody") was indeed a Russian 
national lecturing at New Wye; and that Charles Kinbote (alias the deposed King of Zembla, and yet another nearanagram), the apparently deranged annotator of Shade's cantos, ended up committing suicide, outside the novel itself, as it were. So, finally, compared with FLT, there are several Andrew Wileses (he who finally proved the 300 -year-old conjecture), each of whom is convinced he knows what the novel is all about.

There's more money to be made solving the $\mathrm{P}=\mathrm{NP}$ conjecture (or its converse, the Clifford $\$ 1$ million is unclaimed as I go to press my trousers), but a Pale Fire breakthrough could bring you lasting fame and headlines in the TLS or NYRB. It's not without its computational aspects-namely, carefully constructing hypertext "allusional" graphs not unlike the ones devised by El Don Knuth to illustrate who was sharing carriages and information with whom on Agatha Christie's Orient Express. Even minor Pale Fire discoveries have titillated the Nabokovian world, proving how easy it is to be dis-allusioned. A reference to Edsel Ford was for years taken to be Henry's son or the eponymous, infamous, ill-fated motor car. Matt Roth, a Pale Fire expert, uncovered the shocking coincidence that there was indeed a rather obscure poet born and christened Edsel Ford (1928-70), although, of course, not at all obscure to those who know of him. Indeed, among those who knew him was that omnivore Vladimir Nabokov, who quotes two lines from Ford's sonnet "The Image of Desire" in the novel Pale Fire.

My own Pale Fire solutions include the far-fetched idea that Pale should be pronounced Pally as in Palearctic, the very eco-zone in which every single butterfly nabbed [sic] and classified by Nabokov is to be found. This pale- prefix is a common contraction of paleo- meaning ancient or Old World. When we go a-llusioning, all things are possible. We now have not only pally or friendly fire (or amicide to increase your word-power-why buy Reader's Digest?) in our chain, but productive hints of Promethean fire and unbounded links to Aeschylus, Shelley, and that crowd.

And here we return to mathematics, computer science, and veer toward John Playfair's notion of a porism: “A proposition affirming the possibility of finding such conditions as will render a certain problem indeterminate or capable of innumerable solutions."

Loosely (the word has been through many mangles since Euclid was a lad), we can think of a poristic equation as having either NO solutions or an INFINITE set of solutions. In England, we have the weaker Omnibus Existence Theorem: either NO bus comes to your bus stop or suddenly THREE arrive together. This is Brit Whine 2 , after the Weather Whinge but ahead of the Cricket
Test Match Results Shock. The poristic situation seems bizarre: you'll know that many existence proofs rely on reaching a contradiction after assuming that no solution exists. This familiar reductio ad absurdum (or law of the excluded muddle!) is known as a nonconstructivist approach, in that you may have proved the existence of a solution (at least one) without actually producing any actual solution(s). The limited choice between NO solution and a whole bleeding INFINITY of the buggers is not fair play, my dear Playfair.

I've no evidence that Nabokov ever used the word porism, but it's the sort of arcane word that would delight him. He does use many mathematical terms such as surd and lemniscate (both as the butterfly shape and as infinity on its side). He is acquainted with the higher dimensions of Einstein's space-time (which he attacks without showing a deep understanding of relativity) and speaks of bringing his "expanding universe back to a Newtonian norm." In The Real Life of Sebastian Knight (another cryptic masterpiece devoted to confused identities), he does a bit of Peano by having a character in the novel, closely identified with Nabokov himself, declare that "ONE is the only real number, and everything else comes from addition." Mathematicians would avoid the ambiguity between "real" (actual) and "real" (as in the real number system of which the integers derivable from 1 and + are but a tiny drop in the numerical bucket).

In addition to being an aficionado of butterflies, Nabokov was a skilled chess-problemist, adding to the notion that his literary puzzles might inherit the same challenge of "finding the unique winning solution," as in, "White to play and force mate in three moves." Extending that to the Pale Fire problem is, of course, much more complex. Hence my guess that we are in poristic territory: there may be no solution, but if we do find one, an indefinite number of rivals will have to be accepted.

In his memoir Speak, Memory (ranked in the top 10 of the world's nonfiction!), we can see what a great mathematician Nabokov might have become:

"As a little boy, I showed an abnormal aptitude for mathematics, which I completely lost in my singularly talentless youth. This gift played a horrible part in tussles with quinsy or scarlet fever, when I felt enormous spheres and huge numbers swell relentlessly in my aching brain. A foolish tutor [Nabokov enjoyed a wealthy, multilingual upbringing in Tsarist St. Petersburg] had explained logarithms to me much too early and I had read (in ... 


\section{curmudgeon}

The Boy's Own Paper, I believe) about a certain Hindu calculator who in exactly two seconds could find the seventeenth root of, say [here follows a 40-decimal-digit number] (I am not sure if I have got this right; anyway the root was 212.)"

The remarkable thing here is that the numbers are correct: the 40-digit number is indeed $(212)^{\wedge} 17$. More remarkable is that Nabokov claims to have remembered the numbers from a fleeting childhood event some 40 years previously. (In passing, Underwood Dudley, who knows some of the tricks of the calculating prodigies, tells me that knowing in advance that a given number is in fact the exact 17 th power of some integer really simplifies finding its 17 th root! You readily estimate the range of $x$ from $\log \left(x^{\wedge} 17\right)=17 \log x=\log (N)$. But that leaves the amazing task for most of us to mentally calculate 17 powers.) Nabokov is not claiming to have calculated anything, but had he lied he need only have remembered 212 and 17 and then computed $212^{\wedge} 17$ for his memoirs. This is most unlikely, as is the possibility that his copy of Boy's Own Paper survived the 1917 Revolution and the Nabokov family's subsequent odysseys in Germany, France, and England.

And yet, the more I learn of his life, works, and remarkable brain, the less inclined am I to doubt his word. He suffered (or enjoyed) synesthesia, so he "saw" words, letters, and numbers as colored images. He composed his novels on index cards, and at a certain point had the complete work fixed in his mind. So, if your exposure to Nabokov has been limited to his controversial Lolita (or the movies "they dared not make!"), perhaps the Pale Fire mystery might help widen your horizons. It may perhaps improve your IT career opportunities by sharpening your deductive and word power. Maybe not! Who cares? We'll all be on the dole until the recession ends at 6:12 a.m. GMT on September 15, 2014 (you read it here first).

As that most annoying of adverts says, "Make the Most of NOW!" (I can never recall the product. I just rush at time's moving target, missing one NOW after the next.) Relax with Pale Fire. It's full of laughs, just like my title! As Jeremy Paxman says on the UK game show, University Challenge, "Here's your starter for 10. Which unfinished 999-line poem begins:

"I was the shadow of the waxwing slain By the false azure in the windowpane"?

No conferring!
My quiz this month (usual invaluable prizes): Boyer's law states that "mathematical laws, formulae, and theorems are usually not named after their original discoverers." Who was the first to enunciate this law? 0

\section{REFERENCES}

1. This now-dated slur, I hate to clarify for non-Brits, involves the sad and unfair decline in prestige suffered by certain higher-educational establishments set up in the UK for "vocational" rather than "academic" training. While remaining treasured in France and many other countries, the poly in the UK has been so stigmatized as inferior to its elitist rivals that a truly British solution has been mandated: the polytechnics have been renamed as universities!

2. Unlike coolth, which has been attested dialectically since the 16th century, dumbth is yet to be widely blessed in the dictionaries, in spite of Steve Allen's coinage and a book of that title (Dumbth: The Lost Art of Thinking, Prometheus Books), circa 1996. Allen tries to separate the facts that most people ought to know but occasionally don't know through sheer accident, and those facts or logical steps in reasoning that really, really are so damned widely known and obvious that dumbth rather than ignorance is the only natural explanation. Some of Allen's examples are borderline, however. A classic gotcha is: "Fancy not knowing that Gregory Peck played the title-role in Moby Dick." It's more likely to catch out those who do know the actor and the movie, but are temporarily confused by the meaning of "title-role!"

\section{LOVE IT, HATE IT? LET US KNOW}

feedback@queue.acm.org

STAN KELLY-BOOTLE (http://www.feniks.com/skb/; http:// www.sarcheck.com), born in Liverpool, England, read pure mathematics at Cambridge in the 1950s before tackling the impurities of computer science on the pioneering EDSAC I. His many books include The Devil's DP Dictionary (McGrawHill, 1981), Understanding Unix (Sybex, 1994), and the recent e-book Computer Language-The Stan Kelly-Bootle Reader. Software Development Magazine has named him as the first recipient of the new annual Stan Kelly-Bootle Eclectech Award for his "lifetime achievements in technology and letters." Neither Nobel nor Turing achieved such prized eponymous recognition. Under his nom-de-folk, Stan Kelly, he has enjoyed a parallel career as a singer and songwriter. He can be reached at curmudgeon@acmqueue.com.

(c) 2009 ACM $1542-7730 / 09 / 0200 \$ 5.00$ 